\title{
Rumen biohydrogenation-derived fatty acids in milk fat from grazing dairy cows supplemented with rapeseed, sunflower, or linseed oils
}

\author{
O. A. Rego, ${ }^{* 1}$ S. P. Alves, †¥ L. M. S. Antunes, ${ }^{*}$ H. J. D. Rosa, ${ }^{*}$ C. F. M. Alfaia,§ J. A. M. Prates, $\S$ \\ A. R. J. Cabrita,\# A. J. M. Fonseca, $\ddagger$ and R. J. B. Bessa†§ \\ *Centro de Investigação e Tecnologia Agrária dos Açores (CITA-A), Departamento de Ciências Agrárias, Universidade dos Açores, \\ 9701-851 Angra do Heroísmo, Portugal \\ †Unidade de Produção Animal, Instituto Nacional de Recursos Biológicos, Fonte Boa, 2005-048 Vale de Santarém, Portugal \\ ‡Rede de Química e Tecnologia (REQUIMTE), Instituto de Ciências Biomédicas de Abel Salazar (ICBAS), Universidade do Porto, \\ Campus Agrário de Vairão, Rua Padre Armando Quintas, 4485-661 Vairão VC, Portugal \\ §Centro de Investigação Interdisciplinar em Sanidade Animal (CIISA), Faculdade de Medicina Veterinária, TU Lisbon, Pólo Universitário do Alto \\ da Ajuda, 1300-477 Lisboa, Portugal \\ \#REQUIMTE, Secção Autónoma de Engenharia das Ciências Agrárias (SAECA), Faculdade de Ciências, Universidade do Porto, \\ Campus Agrário de Vairão, Rua Padre Armando Quintas, 4485-661 Vairão VC, Portugal
}

\begin{abstract}
The effects of supplementation with rapeseed, sunflower, and linseed oils $(0.5 \mathrm{~kg} / \mathrm{d}$; good sources of oleic, linoleic, and linolenic acids, respectively) on milk responses and milk fat fatty acid (FA) profile, with special emphasis on rumen-derived biohydrogenation intermediates (BI), were evaluated in a replicated $4 \times$ 4 Latin square study using 16 grazing dairy cows. The dietary treatments were 1) control diet: 20-h access to grazing pasture supplemented with $5 \mathrm{~kg} / \mathrm{d}$ of cornbased concentrate mixture ( $96 \%$ corn; CC); 2) RO diet: 20 -h access to grazing supplemented with $4.5 \mathrm{~kg} / \mathrm{d}$ of $\mathrm{CC}$ and $0.5 \mathrm{~kg}$ of rapeseed oil; 3) SO diet: 20-h access to grazing supplemented with $4.5 \mathrm{~kg} / \mathrm{d}$ of $\mathrm{CC}$ and 0.5 $\mathrm{kg}$ of sunflower oil; and 4) LO diet: 20 -h access to grazing supplemented with $4.5 \mathrm{~kg} / \mathrm{d}$ of $\mathrm{CC}$ and $0.5 \mathrm{~kg}$ of linseed oil. Milk fatty acids were converted to methyl esters and analyzed by gas-liquid chromatography and silver-ion HPLC. Dietary treatments had no effect on milk production or on milk protein content and milk protein production. Supplementation with rapeseed and sunflower oils lowered milk fat content and milk fat production, but linseed oil had no effect. Inclusion of dietary vegetable oils promoted lower concentrations of short-chain (including 4:0) and medium-chain FA (including odd- and branched-chain FA) and 18:3n-3, and higher concentrations of $\mathrm{C}_{18} \mathrm{FA}$ (including stearic and oleic acids). The BI concentration was higher with the dietary inclusion of vegetable oils, although the magnitude of the concentration and its pattern differed between oils. The RO treatment resulted in moderate increases in BI, including trans 18:1 isomers and 18:2
\end{abstract}

Received January 22, 2009.

Accepted May 26, 2009.

${ }^{1}$ Corresponding author: orego@uac.pt trans-7,cis-9, but failed to increase 18:1 trans-11 and 18:2 cis-9,trans-11. Sunflower oil supplementation resulted in the highest concentrations of the 18:1 trans-10, 18:1 cis-12, and 18:2 trans-10,trans-12 isomers. Concentrations of $18: 1$ trans- 11 and $18: 2$ cis-9,trans-11 were higher than with the control and RO treatments but were similar to the LO treatment. Concentration of BI in milk fat was maximal with LO, having the highest concentrations of some 18:1 isomers (i.e., trans-13/14, trans-15, cis-15, cis-16), most of the nonconjugated 18:2 isomers (i.e., trans-11,trans-15, trans-11, cis-15, cis9,cis-15, and cis-12,cis-15), and conjugated 18:2 isomers (i.e., trans-11,cis-13, cis-12,trans-14, trans-11,trans-13, trans-12,trans-14, and trans-9,trans-11), and all conjugated 18:3 isomers. The LO treatment induced the highest amount and diversity of $\mathrm{BI}$ without decreasing milk fat concentration, as the $\mathrm{RO}$ and $\mathrm{SO}$ treatments had, suggesting that the BI associated with 18:3n-3 intake may not be the major contributors to inhibition of mammary milk fat synthesis.

Key words: dairy cow, grazing, milk fatty acid, vegetable oil

\section{INTRODUCTION}

Milk fat produced from pasture has long been known to be rich in unsaturated fatty acids (FA), including trans-octadecenoic acids and isomers of conjugated linoleic acid (CLA). The pasture is a rich source of polyunsaturated FA (PUFA), mainly linolenic acid (18:3n-3), which contribute as precursors of CLA and 18:1 trans-11 (Chilliard et al., 2007). Isomers of CLA are termed to describe a mixture of positional and geometrical isomers of linoleic acid with conjugated double bonds. Edible fat from ruminants is the main source of CLA in the human diet. Rumenic acid (18:2 cis9,trans-11), the main CLA isomer, is produced by some 
rumen bacteria from dietary linoleic acid and by $\Delta^{9}$ desaturase from the 18:1 trans-11 present in animal and human tissues (Shingfield et al., 2008). Some isomers of CLA have been reported to have a wide range of beneficial health effects, such as anticarcinogenic, antiatherogenic, antidiabetic, and antiobesity properties (Shingfield et al., 2008). Therefore, altering the milk fat FA composition in dairy cows through dietary manipulation has gained considerable attention.

Supplementing the TMR diets of dairy cows with unsaturated lipids is generally highly effective in increasing the milk CLA content (Chilliard et al., 2007). The milk produced by grazing dairy herds, such as in the Azorean archipelago, is naturally enriched in CLA (Rego et al., 2008). Nevertheless, further amplification of the milk CLA content would be desirable, allowing a clear market differentiation. Although some information is available on supplementing TMR diets of dairy cows with different sources of vegetable fats (oils or seeds), information on supplementing the diets of grazing dairy cows is scarce (Schroeder et al., 2004). Moreover, detailed information on the profile of $\mathrm{FA}$ isomers derived from $\mathrm{C}_{18}$ PUFA biohydrogenation in the rumen [hereafter termed biohydrogenation intermediates (BI)], including a detailed CLA isomeric profile, on the milk fat from grazing dairy cows supplemented with vegetable oils is lacking. Therefore, the objective of this study was to evaluate the effects of supplementing the diets of grazing dairy cows with rapeseed, sunflower, and linseed oils (good sources of oleic, linoleic, and linolenic FA, respectively) on milk responses and milk fat FA composition, with emphasis on BI, including a detailed CLA isomer profile as determined by HPLC. Additionally, because pasture and linseed oil are both good sources of 18:3n-3, this study aimed to detect any positive additive or synergistic effect between them.

\section{MATERIALS AND METHODS}

\section{Pasture}

The feeding trial was conducted at the Dairy Unit of the Department of Agriculture Sciences, University of Azores (Portugal), from May to August 2006 and followed the European Union animal welfare Directives (European Economic Community, 1986). The production unit is located at an altitude of $400 \mathrm{~m}$ and has approximately 60 milking cows. Animals had access to a permanent pasture, composed of approximately $72 \%$ ryegrass (Lolium perenne L.), 10\% Kentucky bluegrass (Poa pratensis L.), 12\% white clover (Trifolium repens L.), and $6 \%$ weeds (Rumex spp.) and dead matter. Cows grazed paddocks of 2 ha, divided by traditional stone walls, at an herbage allowance of $26 \mathrm{~kg}$ of $\mathrm{DM} / \mathrm{cow}$ per day. Pregrazing pasture mass ( $\mathrm{kg}$ of $\mathrm{DM} / \mathrm{ha}$ ) was measured by cutting 6 quadrats $\left(0.25 \mathrm{~m}^{2}\right)$ to ground level at 3 -d intervals. Target herbage masses varied between 2,500 and 2,900 kg of DM/ha. Strips were grazed for 1 $\mathrm{d}$, and were delimited by mobile electric fences. Drinking water was always available at pasture.

\section{Design, Diets, and Management}

Sixteen multiparous [parity number $4.4(\mathrm{SD}=1.96)$ ] Holstein cows averaging $560 \mathrm{~kg}$ of $\mathrm{BW}(\mathrm{SD}=38.3), 145$ DIM $(\mathrm{SD}=43.9)$, and $27 \mathrm{~kg}$ of milk $/ \mathrm{d}(\mathrm{SD}=5.0)$ were used. Cows were grouped according to milk production, parity, and DIM and were randomly assigned to dietary treatment sequences in a changeover design (four $4 \times$ 4 Latin squares). Each experimental period lasted for 4 wk, 3 wk for diet adaptation followed by 1 wk of data collection. The dietary treatments were 1) control diet: 20 -h access to grazing pasture supplemented with $5 \mathrm{~kg} / \mathrm{d}$ of corn-based concentrate mixture (96\% corn; CC; Table 1); 2) RO diet: 20-h access to grazing pasture supplemented with $4.5 \mathrm{~kg} / \mathrm{d}$ of $\mathrm{CC}$ and $0.5 \mathrm{~kg}$ of rapeseed oil (Tagol, Companhia de Oleaginosas do Tejo, Almada, Portugal); 3) SO diet: 20-h access to grazing pasture supplemented with $4.5 \mathrm{~kg} / \mathrm{d}$ of $\mathrm{CC}$ and $0.5 \mathrm{~kg}$ of sunflower oil (Tagol, Companhia de Oleaginosas do Tejo); and 4) LO diet: 20-h access to grazing pasture supplemented with $4.5 \mathrm{~kg} / \mathrm{d}$ of CC and $0.5 \mathrm{~kg}$ of linseed oil (Tagol, Companhia de Oleaginosas do Tejo). The corn grain was ground in a hammer mill with a 4-mm screen, and the concentrate mixture was prepared in a single batch. The oils were mixed with the concentrate daily. The supplements $(2.5 \mathrm{~kg})$ were offered twice each day in the milking parlor and were completely consumed. Samples of pasture (plucked at $5 \mathrm{~cm}$ from ground level) and concentrates were sampled daily during the last $7 \mathrm{~d}$ of each period and, after oven DM determination $\left(65^{\circ} \mathrm{C}\right.$, $48 \mathrm{~h}$ ), were composited by period. Cows were milked twice daily at 0700 and $1600 \mathrm{~h}$.

Milk production was measured during the last week of each experimental period. Milk was sampled at both milkings on 2 consecutive days during the last week of each experimental period, and proportional composites were analyzed for fat and protein. Milk fat was isolated from individual milk samples, collected on the last day of milk sampling, by centrifugation for 15 min at $822 \times$ $g$ and immediately stored at $-15^{\circ} \mathrm{C}$ until FA analysis. Cows were weighed at the same time of day (following the a.m. milking) on the 2 final days of each experimental period.

\section{Chemical Analysis}

Composite samples of feeds from the last week of each experimental period were submitted for chemical 
Table 1. Chemical analysis and fatty acid composition of experimental feeds

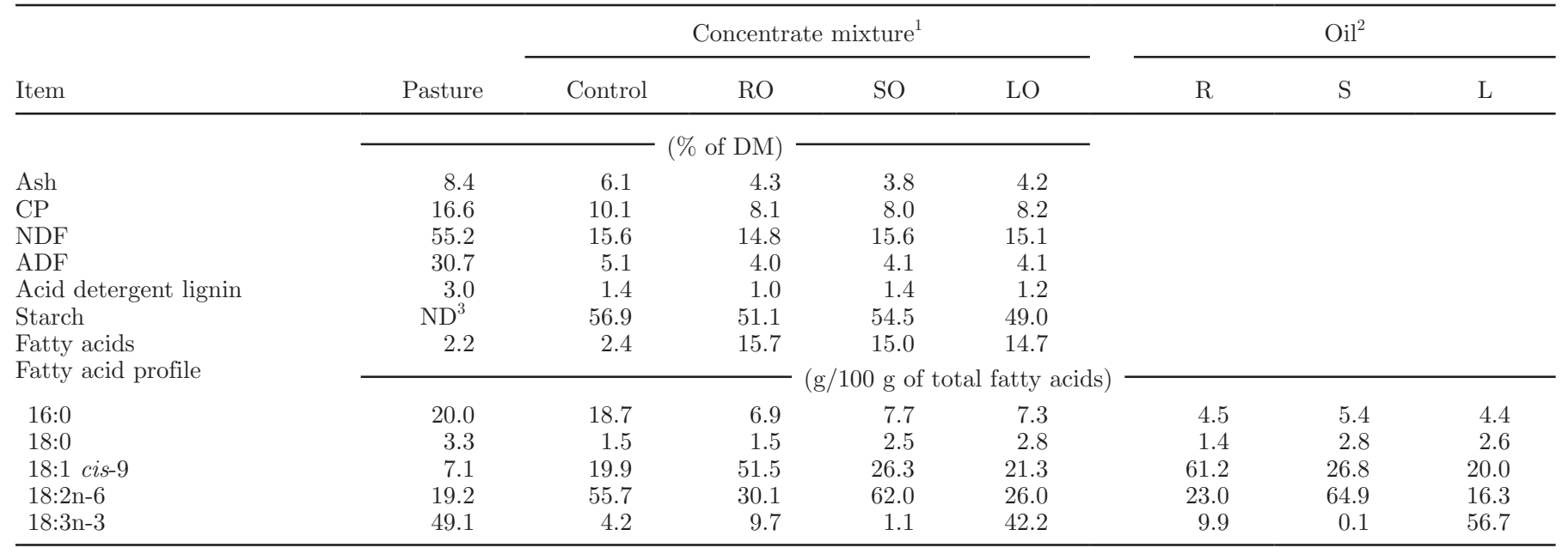

${ }^{1}$ Control $=96 \%$ corn grain, $0.5 \%$ salt, and 3.5\% mineral premix (MINERVET 2/1, Vetagri Alimentar SA, Cantanhede, Portugal); RO $=90 \%$ control diet plus $10 \%$ rapeseed oil; SO $=90 \%$ control diet plus $10 \%$ sunflower oil; $\mathrm{LO}=90 \%$ control diet plus $10 \%$ linseed oil.

${ }^{2} \mathrm{R}=$ rapeseed oil; $\mathrm{S}=$ sunflower oil; $\mathrm{L}=$ linseed oil.

${ }^{3}$ Not determined.

analysis. Ground samples (1 mm) were analyzed for ash (AOAC, 1990; method 942.05) and Kjeldahl N (AOAC, 1990; method 954.01). Crude protein was calculated as Kjeldahl $\mathrm{N} \times 6.25$. Neutral detergent fiber, $\mathrm{ADF}$, and acid detergent lignin were determined by the detergent procedures of Van Soest et al. (1991) and Robertson and Van Soest (1981), with $\alpha$-amylase being added for concentrates during NDF extraction; sodium sulfite was not added. Neutral detergent fiber was expressed without residual ash. Starch was analyzed on finely ground samples (0.5-mm screen) using the method described by Salomonsson et al. (1984). Milk fat and protein were determined by automated infrared analysis with a MilkoScan 605 instrument (Foss Electric, Hillerød, Denmark; AOAC, 1990; method 972.16).

\section{FA Analysis}

Fatty acid methyl esters of feed lipids were prepared by a one-step extraction transesterification procedure according to the method of Sukhija and Palmquist (1988) using 250-mg samples, with heptadecanoic acid as an internal standard. Milk fatty acid methyl esters were prepared by direct transesterification of milk fat (Molkentin and Precht, 2000). Briefly, $50 \mathrm{mg}$ of layer milk fat was dissolved in $1 \mathrm{~mL}$ of $n$-hexane, and after addition of $0.2 \mathrm{~mL}$ of potassium hydroxide $(2 \mathrm{~N}$ in methanol), the solution was shaken vigorously for 3 min and was left to stand for $1 \mathrm{~h}$. After addition of 100 $\mathrm{mg}$ of sodium sulfate, the solution was mixed again and centrifuged for 5 min at $1,000 \times g$ and the supernatant was transferred to GLC vials. Fatty acid methyl esters were analyzed using an HP6890A gas chromatograph
(Hewlett-Packard, Avondale, PA) equipped with a flame-ionization detector and a fused-silica capillary column (CP-Sil 88; $100 \mathrm{~m}$; 0.25 mm i.d.; 0.20-mm film thickness; Chrompack, Varian Inc., Walnut Creek, CA). Helium was used as the carrier gas, and the injector and detector temperatures were 250 and $280^{\circ} \mathrm{C}$, respectively. The split ratio was 50:1, and the injection volume was $1 \mu \mathrm{L}$. Two temperature programs were applied. The first was used for identification of mediumand long-chain FA and to achieve good separation of major 18:1 isomers; the initial temperature column of $100^{\circ} \mathrm{C}$ was held for $15 \mathrm{~min}$, increased to $150^{\circ} \mathrm{C}$ at a rate of $10^{\circ} \mathrm{C} / \mathrm{min}$ and held for $5 \mathrm{~min}$, then increased to $158^{\circ} \mathrm{C}$ at $1^{\circ} \mathrm{C} / \mathrm{min}$ and held for $30 \mathrm{~min}$, and finally increased to $200^{\circ} \mathrm{C}$ at a rate of $1^{\circ} \mathrm{C} / \mathrm{min}$ and maintained for $65 \mathrm{~min}$. A second temperature program was used for quantification of short-chain FA, as well as for resolution of 18:1 trans-13 + trans-14 isomers from 18:1 cis-9; the initial column temperature of $50^{\circ} \mathrm{C}$ was held for $4 \mathrm{~min}$, increased to $175^{\circ} \mathrm{C}$ at a rate of $13^{\circ} \mathrm{C} / \mathrm{min}$ and held for $27 \mathrm{~min}$, and then increased to $215^{\circ} \mathrm{C}$ at $4^{\circ} \mathrm{C} /$ min and maintained for $60 \mathrm{~min}$. Theoretical response factors were used to correct peak areas of short-chain FA with carbon chain lengths of less than 14. Identification of common FA was accomplished by comparing sample peak retention times with those of FA methyl ester standard mixtures (Sigma, St. Louis, MO) and, when no commercial standards were available, by using published chromatograms obtained under similar analytical conditions (Cruz-Hernandez et al., 2004; Alves and Bessa, 2007), by synthesis of $18: 2$ cis-9, cis- 15 and 18:2 cis-12,cis-15 as described in Alves and Bessa (2007), and by synthesis of other nonconjugated isomers 


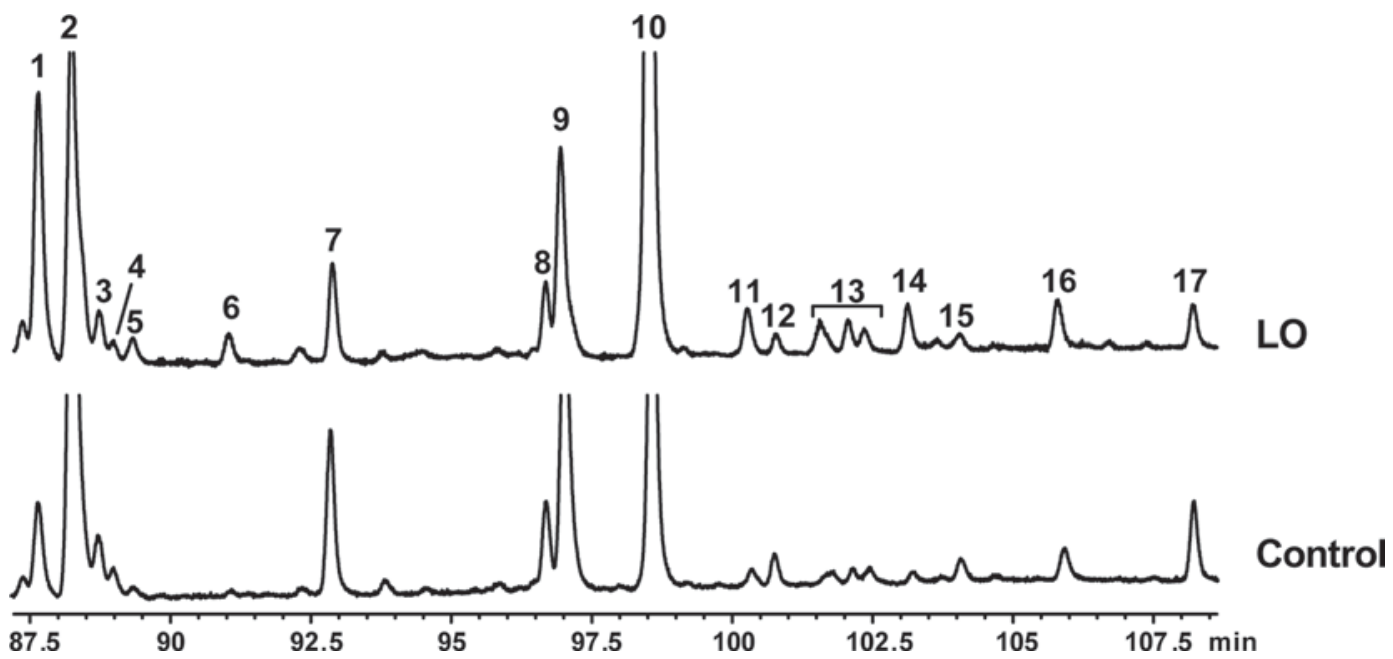

Figure 1. Partial gas chromatogram of milk fat from grazing cows feed linseed oil (LO) and control diets. Peak identification: 1) 18:2 trans11,cis-15; 2) 18:2n-6; 3) 19:1;4) 19:1; 5) 18:2 cis-9,cis-15;6) 18:2 cis-12,cis-15; 7) 20:0; 8) 20:1 cis-11; 9) 18:3n-3; 10) 18:2 cis-9,trans-11;11) 18:2 trans-11,cis-13; 12) 21:0 + conjugated linoleic acid (CLA); 13) trans,trans CLA; 14) 18:3 cis-9,trans-13,cis-15; 15) 20:2n-6; 16) 18:3 cis-9, trans11, cis-15; 17) 22:0.

(18:2 trans-9,cis-12 and 18:2 cis-9,trans-12) from the isomerization reaction of linoleic acid with iodine and UV light (Delmonte et al., 2003). Additionally, a Varian Saturn 2200 gas chromatograph-mass spectrometer (Varian Inc.) equipped with an ion trap mass detector and a CP-Sil 88 capillary column $(100 \mathrm{~m}, 0.25 \mathrm{~mm}$ i.d., $0.20 \mathrm{~mm}$ film thickness, Chrompack, Varian Inc.) was used for identification of cis-9,trans-11,cis-15 and cis-9,trans-13,cis-15 18:3 isomers in milk fat samples. The GC-MS parameters and conditions are described in Alves and Bessa (2007). For identification of those isomers, a mixture of 18:3 partially conjugated isomers was prepared by the conjugation reaction of linolenic acid (18:3 cis-9,cis-12,cis-15) with a $6.6 \% \mathrm{KOH}$ solution in ethylene glycol for $2 \mathrm{~h}$ at $150^{\circ} \mathrm{C}$ under $\mathrm{N}_{2}$ (Delmonte et al., 2003). 4,4-Dimethylloxazoline derivatives from samples and from partially conjugated 18:3 isomers were prepared (Luthria and Sprecher, 1993) and analyzed by GC-MS to identify cis-9,trans-11,cis-15 and cis-9,trans-13,cis-15 18:3 isomers in milk fat samples. A partial gas chromatogram of the region where these isomers eluted is shown in Figure 1.

The CLA methyl ester isomers were separated by silver-ion HPLC as described by Rego et al. (2008). Briefly, analyses were conducted on an HPLC system (Agilent 1100 Series, Agilent Technologies Inc., Avondale, PA) equipped with 3 silver ion columns in series (Chrom-Spher 5 Lipids, $250 \mathrm{~mm} \times 4.6 \mathrm{~mm}$ i.d., $5-\mu \mathrm{m}$ particle size, Chrompack, Bridgewater, NJ). Standards of CLA isomers (cis-9,trans-11, trans-10, cis-12, cis9,cis-11, and trans-9,trans-11) as methyl esters were purchased from Matreya Inc. (Pleasant Gap, PA). Identification of the individual CLA isomers was achieved by comparison of their retention times with those of commercial standards and with values published in the literature (Cruz-Hernandez et al., 2004). In addition, the identity of each isomer was controlled by the typical UV spectra of CLA isomers from the diode array detector in the range 190 to $360 \mathrm{~nm}$, using the spectral analysis of Agilent Chemstation (Agilent Technologies, 2001) for LC 3D Systems Rev. A.09.01. Fatty acid composition was expressed as grams per kilogram of total FA composition by using theoretical response factors for FA with chain lengths of less than 14. Amounts of the CLA isomers were calculated from their silver-ion HPLC areas relative to the area of the main CLA isomer 18:2 cis-9,trans-11 identified by GC (which constitutes both trans-7,cis-9 and trans-8,cis-10 CLA isomers). Fatty acid yields (g/d) were computed according to the method of Glasser et al. (2007a).

\section{Statistical Analysis}

Data on milk production and milk composition from the last week of each experimental period and FA profiles of milk samples were analyzed as replicated 4 $\times 4$ Latin squares, using the MIXED procedure (SAS Institute Inc., Cary, NC). The model included the fixed effects of square, period, and dietary treatment, the random effect of cow within square, and the random residual error. When differences were significant $(P<$ 0.05), Tukey's test was used to compare means.

The relationship between milk fat content and milk BI was evaluated by using the MIXED procedure (SAS Institute Inc.) with the inclusion of the random effect of cow within square as described by St-Pierre (2001). 
Table 2. Least squares means for milk production, milk composition, and BW from the different dietary treatments ${ }^{1}$

\begin{tabular}{lcccccc}
\hline Item & Control & RO & SO & LO & SEM & $P$-value \\
\hline Milk & & & & & & \\
Yield, $\mathrm{kg} / \mathrm{d}$ & 22.2 & 21.9 & 22.0 & 22.2 & 0.52 & 0.821 \\
ECM $^{2} \mathrm{~kg} / \mathrm{d}$ & $23.4^{\mathrm{a}}$ & $21.8^{\mathrm{bc}}$ & $21.7^{\mathrm{bc}}$ & $22.7^{\mathrm{ac}}$ & 0.58 & 0.007 \\
Fat, $\%$ & $3.75^{\mathrm{a}}$ & $3.33^{\mathrm{b}}$ & $3.27^{\mathrm{b}}$ & $3.59^{\mathrm{a}}$ & 0.103 & $<0.001$ \\
Protein, $\%$ & 3.51 & 3.45 & 3.45 & 3.43 & 0.054 & 0.141 \\
Fat, $\mathrm{kg} / \mathrm{d}$ & $0.82^{\mathrm{a}}$ & $0.72^{\mathrm{b}}$ & $0.70^{\mathrm{b}}$ & $0.78^{\mathrm{a}}$ & 0.028 & 0.001 \\
Fatty acids, kg/d & $0.77^{\mathrm{a}}$ & $0.69^{\mathrm{b}}$ & $0.66^{\mathrm{b}}$ & $0.73^{\mathrm{a}}$ & 0.026 & 0.001 \\
Protein, $\mathrm{kg} / \mathrm{d}$ & 0.78 & 0.75 & 0.75 & 0.76 & 0.018 & 0.415 \\
BW, kg & $555^{\mathrm{a}}$ & $565^{\mathrm{ab}}$ & $564^{\mathrm{ab}}$ & $566^{\mathrm{b}}$ & 12.0 & 0.033 \\
\hline
\end{tabular}

${ }^{\mathrm{a}-\mathrm{C}}$ Values in the same row that share a common superscript are not statistically different $(P>0.05)$.

${ }^{1}$ Treatments: control $=20$-h access to grazing pasture supplemented with $5 \mathrm{~kg} / \mathrm{d}$ of corn-based concentrate mixture (96\% corn; CC); $\mathrm{RO}=20$-h access to grazing pasture supplemented with $4.5 \mathrm{~kg} / \mathrm{d}$ of CC and $0.5 \mathrm{~kg}$ of rapeseed oil; $\mathrm{SO}=20$-h access to grazing pasture supplemented with $4.5 \mathrm{~kg} / \mathrm{d}$ of CC and $0.5 \mathrm{~kg}$ of sunflower oil; $\mathrm{LO}=20$-h access to grazing pasture supplemented with $4.5 \mathrm{~kg} / \mathrm{d}$ of $\mathrm{CC}$ and $0.5 \mathrm{~kg}$ of linseed oil.

${ }^{2}$ Calculated as $(0.324 \times \mathrm{kg}$ of milk $)+(12.95 \times \mathrm{kg}$ of milk fat $)+(7.20 \times \mathrm{kg}$ of milk protein $)$.

The observed milk fat content was adjusted for cow within square effects by adding each residual to its corresponding $\mathrm{Y}$ predicted value according to the method of St-Pierre (2001).

\section{RESULTS}

Table 1 shows the chemical and FA composition of feeds and oils. Pasture was a good source of 18:3n-3 and ground corn (Zea mays) was rich in 18:2n-6. As expected, the most representative FA in oils were 18:1 cis-9, 18:2n-6, and 18:3n-3, respectively, in rapeseed, sunflower, and linseed oils.

\section{Milk Production and Milk Composition}

Milk response data are summarized in Table 2. Milk production, and milk protein content and production were not affected by treatments. Supplementation with rapeseed and sunflower oils decreased milk fat content and production, with linseed oil having no effect. Energy-corrected milk decreased with oil supplementation, except for LO. Body weight of cows was higher with oil supplementation.

\section{Milk FA Composition}

The dietary effects on milk FA profiles (excluding BI) are given in Table 3. Supplementation with vegetable oils decreased butyric acid (4:0), and other short-chain (6:0, 8:0, 10:0, and 12:0) and medium-chain (14:0, 14:1 cis-9, 16:0, and 16:1 cis-9) FA. The most representative medium-chain FA (i.e., 12:0, 14:0, and 16:0) decreased, respectively, by 42,33 , and $26 \%$ with oil supplementation. Odd- and branched-chain FA were reduced with inclusion of oils. Oleic acid (18:1 cis-9) increased by $36 \%$ with RO and SO and by only $20 \%$ with LO, whereas 18:0 increased, on average, by $18.6 \%$ with the oil treatments. Excluding the SO diet, which promoted an increase in 18:2n-6, both the RO and LO diets decreased 18:2n-6 concentration. Dietary inclusion of oils lowered 18:3n-3 concentration in milk fat. The decrease was $33 \%$ for RO and $\mathrm{SO}$ and $12 \%$ for $\mathrm{LO}$.

The percentages of total FA and yields of selected partial sums of FA are presented in Table 4. All dietary oils lowered $(-17.4 \%)$ the sum of saturated FA equally and increased the sum of cis-MUFA, although this effect was lower for the LO diet $(+19 \%)$ than for the RO and SO diets $(+32 \%)$. The sum cis-PUFA (methylene interrupted with all cis double bonds) decreased by $12 \%$, and the sums of trans FA, either total trans FA or the partial sum of trans FA (excluding FA with conjugated double bonds and 18:1 trans-11) increased with oil supplementation, with the greatest increase in trans FA being found with the LO diet. The concentration of $\mathrm{C}_{18}$ FA in milk fat increased by $31 \%$ with all oilsupplemented diets, whereas the sum of branched-chain FA decreased by $21 \%$.

Fatty acid yields $(\mathrm{g} / \mathrm{d})$ reflected both the fat yield and the FA pattern. Yields of short- and medium-chain FA ( $\leq 14$-carbon FA) decreased with oil supplementation, although this effect was lower with the LO treatment $(-32 \%)$ than with the RO and SO treatments $(-44 \%)$. The saturated FA and cis-PUFA yield decreased with oil supplementation, although this effect was lower with the LO treatment than with the SO treatments, with $\mathrm{RO}$ showing an intermediate response. The yield of $\mathrm{C}_{18} \mathrm{FA}$ increased with all oil supplements, although the effect was greater with $\mathrm{LO}(+23 \%)$ than with SO (+13\%), with RO showing an intermediate response. The cis-MUFA yield increased equally with all oil supplements. The yield of 18:2 cis-9,trans-11 (not 
Table 3. Least squares means for concentration of fatty acids $(\mathrm{mg} / \mathrm{g}$ of fatty acids) in milk fat from the different dietary treatments ${ }^{1}$

\begin{tabular}{|c|c|c|c|c|c|c|}
\hline Fatty acid & Control & $\mathrm{RO}$ & $\mathrm{SO}$ & $\mathrm{LO}$ & SEM & $P$-value \\
\hline 4:0 & $18.7^{\mathrm{a}}$ & $15.8^{\mathrm{bc}}$ & $13.8^{\mathrm{c}}$ & $16.7^{\mathrm{ab}}$ & 0.76 & 0.001 \\
\hline $6: 0$ & $14.0^{\mathrm{a}}$ & $9.9^{\mathrm{b}}$ & $8.7^{\mathrm{c}}$ & $10.6^{\mathrm{b}}$ & 0.47 & $<0.001$ \\
\hline 8:0 & $9.7^{\mathrm{a}}$ & $5.9^{\mathrm{b}}$ & $5.3^{\mathrm{c}}$ & $6.5^{\mathrm{b}}$ & 0.29 & $<0.001$ \\
\hline $10: 0$ & $23.3^{\mathrm{a}}$ & $12.9^{\mathrm{c}}$ & $11.5^{\mathrm{d}}$ & $14.1^{\mathrm{b}}$ & 0.73 & $<0.001$ \\
\hline $10: 1$ cis -9 & $2.9^{\mathrm{a}}$ & $1.6^{\mathrm{bc}}$ & $1.5^{\mathrm{c}}$ & $1.8^{\mathrm{b}}$ & 0.12 & $<0.001$ \\
\hline $12: 0$ & $28.3^{\mathrm{a}}$ & $16.3^{\mathrm{bc}}$ & $15.2^{\mathrm{c}}$ & $17.5^{\mathrm{b}}$ & 0.79 & $<0.001$ \\
\hline iso-13:0 & $0.6^{\mathrm{a}}$ & $0.4^{\mathrm{b}}$ & $0.4^{\mathrm{b}}$ & $0.4^{\mathrm{b}}$ & 0.02 & $<0.001$ \\
\hline $12: 1$ trans -9 & $0.8^{\mathrm{a}}$ & $0.5^{\mathrm{b}}$ & $0.4^{\mathrm{b}}$ & $0.5^{\mathrm{b}}$ & 0.04 & $<0.001$ \\
\hline $13: 0+12: 1$ & $1.6^{\mathrm{a}}$ & $1.1^{\mathrm{b}}$ & $1.1^{\mathrm{b}}$ & $1.1^{\mathrm{b}}$ & 0.07 & $<0.001$ \\
\hline iso-14:0 & $1.5^{\mathrm{a}}$ & $1.1^{\mathrm{bc}}$ & $1.2^{\mathrm{b}}$ & $1.0^{\mathrm{c}}$ & 0.05 & $<0.001$ \\
\hline $14: 0$ & $102^{\mathrm{a}}$ & $69.0^{\mathrm{bc}}$ & $66.1^{\mathrm{c}}$ & $70.9^{\mathrm{b}}$ & 2.31 & $<0.001$ \\
\hline iso-15:0 & $3.6^{\mathrm{a}}$ & $2.4^{\mathrm{b}}$ & $2.4^{\mathrm{b}}$ & $2.4^{\mathrm{b}}$ & 0.06 & $<0.001$ \\
\hline anteiso-15:0 & $7.0^{\mathrm{a}}$ & $5.5^{\mathrm{b}}$ & $5.7^{\mathrm{b}}$ & $5.6^{\mathrm{b}}$ & 0.18 & $<0.001$ \\
\hline $14: 1$ cis -9 & $9.2^{\mathrm{a}}$ & $6.8^{\mathrm{b}}$ & $7.4^{\mathrm{b}}$ & $6.6^{\mathrm{b}}$ & 0.72 & $<0.001$ \\
\hline $15: 0$ & $12.4^{\mathrm{a}}$ & $10.7^{\mathrm{b}}$ & $10.9^{\mathrm{b}}$ & $10.8^{\mathrm{b}}$ & 0.36 & $<0.001$ \\
\hline iso-16:0 & $0.33^{\mathrm{a}}$ & $0.24^{\mathrm{b}}$ & $0.25^{\mathrm{b}}$ & $0.24^{\mathrm{b}}$ & 0.12 & $<0.001$ \\
\hline $16: 0$ & $241^{\mathrm{a}}$ & $180^{\mathrm{b}}$ & $182^{\mathrm{b}}$ & $170^{\mathrm{b}}$ & 3.30 & $<0.001$ \\
\hline $16: 1$ trans -9 & $1.4^{\mathrm{b}}$ & $1.4^{\mathrm{b}}$ & $2.0^{\mathrm{a}}$ & $2.0^{\mathrm{a}}$ & 0.13 & 0.004 \\
\hline iso- $17: 0$ & $5.1^{\mathrm{a}}$ & $4.4^{\mathrm{c}}$ & $4.7^{\mathrm{b}}$ & $4.7^{\mathrm{b}}$ & 0.09 & $<0.001$ \\
\hline $16: 1$ cis-7 & $2.6^{\mathrm{a}}$ & $3.1^{\mathrm{b}}$ & $3.2^{\mathrm{b}}$ & $3.2^{\mathrm{b}}$ & 0.09 & $<0.001$ \\
\hline 16:1 cis-9 & $10.0^{\mathrm{a}}$ & $9.0^{\mathrm{ab}}$ & $9.9^{\mathrm{a}}$ & $8.4^{\mathrm{b}}$ & 0.68 & 0.009 \\
\hline anteiso-17:0 & $6.0^{\mathrm{a}}$ & $4.5^{\mathrm{c}}$ & $4.9^{\mathrm{b}}$ & $4.6^{\mathrm{c}}$ & 0.12 & $<0.001$ \\
\hline $17: 0$ & $6.4^{\mathrm{a}}$ & $5.2^{\mathrm{b}}$ & $5.3^{\mathrm{b}}$ & $5.1^{\mathrm{b}}$ & 0.10 & $<0.001$ \\
\hline $17: 1$ cis-8 & 0.9 & 0.9 & 0.9 & 0.8 & 0.05 & 0.552 \\
\hline $17: 1$ cis-9 & $2.4^{\mathrm{a}}$ & $2.2^{\mathrm{b}}$ & $2.2^{\mathrm{ab}}$ & $2.0^{\mathrm{c}}$ & 0.12 & 0.001 \\
\hline 18:0 & $143^{\mathrm{b}}$ & $173^{\mathrm{a}}$ & $168^{\mathrm{a}}$ & $168^{\mathrm{a}}$ & 6.20 & $<0.001$ \\
\hline 18:1 cis-9 & $221^{\mathrm{c}}$ & $306^{\mathrm{a}}$ & $296^{\mathrm{a}}$ & $265^{\mathrm{b}}$ & 7.00 & $<0.001$ \\
\hline $18: 2 n-6$ & $11.2^{\mathrm{a}}$ & $9.8^{\mathrm{c}}$ & $12.5^{\mathrm{b}}$ & $9.9^{\mathrm{c}}$ & 0.39 & $<0.001$ \\
\hline $20: 0$ & $2.1^{\mathrm{b}}$ & $3.2^{\mathrm{a}}$ & $2.2^{\mathrm{b}}$ & $2.0^{\mathrm{b}}$ & 0.17 & $<0.001$ \\
\hline $18: 3 n-3$ & $6.0^{\mathrm{a}}$ & $3.8^{\mathrm{c}}$ & $4.2^{\mathrm{c}}$ & $5.3^{\mathrm{b}}$ & 0.20 & $<0.001$ \\
\hline $20: 1$ cis- 11 & $1.3^{\mathrm{b}}$ & $2.1^{\mathrm{a}}$ & $1.4^{\mathrm{b}}$ & $1.2^{\mathrm{b}}$ & 0.06 & $<0.001$ \\
\hline $22: 0$ & $1.0^{\mathrm{a}}$ & $1.0^{\mathrm{a}}$ & $1.0^{\mathrm{a}}$ & $0.7^{\mathrm{b}}$ & 0.04 & $<0.001$ \\
\hline $20: 3 n-6$ & $0.8^{\mathrm{a}}$ & $0.6^{\mathrm{bc}}$ & $0.6^{\mathrm{b}}$ & $0.5^{\mathrm{c}}$ & 0.04 & $<0.001$ \\
\hline $20: 4 n-6$ & $1.0^{\mathrm{a}}$ & $0.6^{\mathrm{b}}$ & $0.6^{\mathrm{b}}$ & $0.6^{\mathrm{b}}$ & 0.03 & $<0.001$ \\
\hline $20: 5 n-3$ & $0.7^{\mathrm{a}}$ & $0.5^{\mathrm{bc}}$ & $0.4^{\mathrm{b}}$ & $0.5^{\mathrm{b}}$ & 0.03 & $<0.001$ \\
\hline $23: 0$ & $0.5^{\mathrm{a}}$ & $0.4^{\mathrm{b}}$ & $0.4^{\mathrm{b}}$ & $0.3^{\mathrm{b}}$ & 0.02 & $<0.001$ \\
\hline $24: 0$ & $0.7^{\mathrm{a}}$ & $0.5^{\mathrm{b}}$ & $0.5^{\mathrm{b}}$ & $0.4^{\mathrm{c}}$ & 0.03 & $<0.001$ \\
\hline Unidentified & $14.5^{\mathrm{a}}$ & $13.6^{\mathrm{ab}}$ & $12.2^{\mathrm{b}}$ & $12.0^{\mathrm{b}}$ & 0.61 & 0.011 \\
\hline
\end{tabular}

${ }^{\mathrm{a}-\mathrm{d}}$ Values in the same row that share a common superscript are not statistically different $(P>0.05)$.

${ }^{1}$ Treatments: control $=20$-h access to grazing pasture supplemented with $5 \mathrm{~kg} / \mathrm{d}$ of corn-based concentrate mixture $(96 \%$ corn; CC); $\mathrm{RO}=20$-h access to grazing pasture supplemented with $4.5 \mathrm{~kg} / \mathrm{d}$ of $\mathrm{CC}$ and $0.5 \mathrm{~kg}$ of rapeseed oil; $\mathrm{SO}=20$-h access to grazing pasture supplemented with $4.5 \mathrm{~kg} / \mathrm{d}$ of CC and $0.5 \mathrm{~kg}$ of sunflower oil; $\mathrm{LO}=20$-h access to grazing pasture supplemented with $4.5 \mathrm{~kg} / \mathrm{d}$ of CC and $0.5 \mathrm{~kg}$ of linseed oil.

shown in Table 3) decreased on the control treatment from 9.0 to $7.5 \mathrm{~g} / \mathrm{d}$ but increased to $10.7 \mathrm{~g} / \mathrm{d}$ with the $\mathrm{SO}$ and $\mathrm{RO}$ diets.

\section{BI}

Fatty acids derived directly from rumen biohydrogenation as well as indirectly because of $\Delta^{9}$-desaturation are presented in Table 5 . The inclusion of vegetable oils increased the concentration of $\mathrm{BI}$, although the magnitude of the increase and the pattern differed between oils. The BI was higher from rapeseed to sunflower and linseed oils. The RO diet supplied mostly 18:1 cis-9, resulting in lower total BI concentration. The increase was mainly due to $18: 1$ isomers, with the notable exception of 18:1 trans-11. The response of total 18:1 BI isomers was higher for the LO diet, followed by the SO, RO, and control diets, although differences in individual isomers were detectable. The 18:1 trans-11 (vaccenic acid) observed with the $\mathrm{RO}$ and SO treatments did not significantly differ from that of the control treatment. The 18:1 trans-11 observed with the LO treatment was higher than with the control treatment but did not differ from that with the SO treatment. The 18:1 trans-10 increased with oil supplementation but was highest with the SO diet. The linseed oil diet induced a greater increase in unresolved peaks of trans-13/trans-14 and trans-16/cis-14 and of the trans-15, cis-15, and cis-16 18:1 isomers. The RO treatment did not increase the $18: 2$ and 18:3 BI, with the exception of the CLA isomer 18:2 trans-7, cis-9 and the unresolved peaks of 18:2 cis-9,trans-13/18:2 trans- 
Table 4. Least squares means for partial sums of the milk fatty acid (FA) profile (mg/g of fatty acids) and production $(\mathrm{g} / \mathrm{d})$ from different dietary treatments ${ }^{1}$

\begin{tabular}{|c|c|c|c|c|c|c|}
\hline Fatty acid & Control & $\mathrm{RO}$ & $\mathrm{SO}$ & $\mathrm{LO}$ & SEM & $P$-value \\
\hline \multicolumn{7}{|c|}{ Partial sum, $\mathrm{mg} / \mathrm{g}$ of $\mathrm{FA}$} \\
\hline$\leq \mathrm{C}_{14} \mathrm{FA}^{2}$ & $213^{\mathrm{a}}$ & $141^{\mathrm{bc}}$ & $133^{\mathrm{c}}$ & $148^{\mathrm{b}}$ & 4.89 & $<0.001$ \\
\hline $\mathrm{OBCFA}^{3}$ & $46.7^{\mathrm{a}}$ & $37.3^{\mathrm{b}}$ & $38.7^{\mathrm{b}}$ & $37.7^{\mathrm{b}}$ & 0.73 & $<0.001$ \\
\hline $\mathrm{C}_{18} \mathrm{FA}^{4}$ & $461^{\mathrm{b}}$ & $604^{\mathrm{a}}$ & $610^{\mathrm{a}}$ & $601^{\mathrm{a}}$ & 7.99 & $<0.001$ \\
\hline Saturated $\mathrm{FA}^{5}$ & $630^{\mathrm{a}}$ & $525^{\mathrm{b}}$ & $513^{\mathrm{b}}$ & $524^{\mathrm{b}}$ & 7.83 & $<0.001$ \\
\hline Cis-MUFA ${ }^{6}$ & $261^{\mathrm{c}}$ & $348^{\mathrm{a}}$ & $341^{\mathrm{a}}$ & $311^{\mathrm{b}}$ & 7.49 & $<0.001$ \\
\hline Cis-PUFA ${ }^{7}$ & $19.7^{\mathrm{a}}$ & $15.3^{\mathrm{c}}$ & $18.3^{\mathrm{b}}$ & $18.5^{\mathrm{b}}$ & 0.55 & $<0.001$ \\
\hline Total trans $\mathrm{FA}^{8}$ & $68.7^{\mathrm{d}}$ & $92.9^{\mathrm{c}}$ & $110.6^{\mathrm{b}}$ & $129.3^{\mathrm{a}}$ & 4.44 & $<0.001$ \\
\hline Partial trans $\mathrm{FA}^{9}$ & $27.2^{\mathrm{d}}$ & $53.2^{\mathrm{c}}$ & $58.6^{\mathrm{b}}$ & $71.3^{\mathrm{a}}$ & 2.39 & $<0.001$ \\
\hline \multicolumn{7}{|l|}{ Partial sum, g/d } \\
\hline$\leq \mathrm{C}_{14} \mathrm{FA}$ & $164^{\mathrm{a}}$ & $96^{\mathrm{c}}$ & $88^{c}$ & $111^{\mathrm{b}}$ & 6.28 & $<0.001$ \\
\hline$\overline{\mathrm{OBCFA}}$ & $35.9^{\mathrm{a}}$ & $25.0^{\mathrm{b}}$ & $25.4^{\mathrm{b}}$ & $27.6^{\mathrm{b}}$ & 1.18 & $<0.001$ \\
\hline $\mathrm{C}_{18} \mathrm{FA}$ & $353^{\mathrm{d}}$ & $402^{\mathrm{bc}}$ & $399^{\mathrm{c}}$ & $434^{\mathrm{ab}}$ & 14.4 & $<0.001$ \\
\hline Saturated FA & $484^{\mathrm{a}}$ & $354^{\mathrm{cd}}$ & $339^{\mathrm{d}}$ & $385^{\mathrm{bc}}$ & 18.3 & $<0.001$ \\
\hline Cis-MUFA & $197^{\mathrm{b}}$ & $228^{\mathrm{a}}$ & $220^{\mathrm{a}}$ & $222^{\mathrm{a}}$ & 7.41 & 0.021 \\
\hline Cis-PUFA & $15.1^{\mathrm{a}}$ & $10.2^{\mathrm{d}}$ & $11.9^{\mathrm{c}}$ & $13.4^{\mathrm{b}}$ & 0.58 & $<0.001$ \\
\hline
\end{tabular}

${ }^{\mathrm{a}-\mathrm{d}}$ Values in the same row that share a common superscript are not statistically different $(P>0.05)$.

${ }^{1}$ Treatments: control $=20$ - $\mathrm{h}$ access to grazing pasture supplemented with $5 \mathrm{~kg} / \mathrm{d}$ of corn-based concentrate mixture $(96 \%$ corn; $\mathrm{CC}) ; \mathrm{RO}=20$-h access to grazing pasture supplemented with $4.5 \mathrm{~kg} / \mathrm{d}$ of $\mathrm{CC}$ and $0.5 \mathrm{~kg}$ of rapeseed oil; $\mathrm{SO}=20$-h access to grazing pasture supplemented with $4.5 \mathrm{~kg} / \mathrm{d}$ of CC and $0.5 \mathrm{~kg}$ of sunflower oil; $\mathrm{LO}=20$-h access to grazing pasture supplemented with $4.5 \mathrm{~kg} / \mathrm{d}$ of $\mathrm{CC}$ and $0.5 \mathrm{~kg}$ of linseed oil.

${ }^{2}$ Sum of all FA with chain lengths $\leq 14$ carbons.

${ }^{3}$ Sum of the odd-chain FA and the branched-chain FA.

${ }^{4} \mathrm{Sum}$ of all FA with chain lengths of 18 carbons.

${ }^{5}$ Sum of all saturated FA.

${ }^{6} \mathrm{Sum}$ of all monounsaturated FA with a cis conformation double bond.

${ }^{7}$ Sum of all cis and methylene-interrupted polyunsaturated FA.

${ }^{8}$ Sum of all FA with at least one trans double bond.

${ }^{9} \mathrm{Sum}$ of all FA with at least one trans double bond except FA with conjugated double bonds and 18:1 trans-11.

8,cis-13 and 18:2 cis- 9 ,trans- $12 / 18: 2$ trans- 8 , cis- 12 . The LO diet greatly increased the proportions of almost all nonconjugated 18:2 as well as conjugated 18:2 and 18:3 isomers. The exceptions were 18:2 trans-10,trans-12, which was higher in SO; 18:2 trans-7, cis-9, which was higher in RO; and 18:2 cis-9,trans-11, which did not differ between $\mathrm{SO}$ and LO. An increase of approximately $30 \%$ in 18:2 cis-9,trans-11 (rumenic acid) in milk fat was achieved by both the SO and LO diets. The 18:2 cis-9,trans-11 represented $87 \%$ of the total CLA in both the control and SO diets but represented only $80 \%$ in the LO diet. Negative relationships between milk fat content and milk BI are presented in Table 6 . The highest $\mathrm{R}^{2}$ were found for 18:1 trans-10, 18:1 cis-11, and 18:2 trans- 7, cis- 9 .

\section{DISCUSSION}

\section{Milk Production and Milk Composition}

These results for milk production and composition are supported by a previous report by Rego et al. (2005), working in similar conditions and supplementing (0.5 $\mathrm{kg} / \mathrm{d}$ ) grazing dairy cows with sunflower and soybean oils. In general, supplementation of grazing dairy cows with unsaturated fat $(0.2$ to $1.0 \mathrm{~kg} / \mathrm{d})$ significantly decreases milk fat concentration $(-8 \%)$ and production, as reviewed by Schroeder et al. (2004). However, the responses can be quite variable with the lipid source used. Lawless et al. (1998), who supplemented grazing dairy cows with full-fat soybeans and full-fat rapeseed $(1.65 \mathrm{~kg} / \mathrm{d}$; approximately $0.65 \mathrm{~kg}$ of oil), observed a decrease in milk fat (only for full-fat rapeseed) and protein content without effects on milk and milk solids production, when compared with a control diet. In accordance with our results, recent data reported by Flowers et al. (2008), who supplemented diets with increasing levels of linseed oil $(0.17,0.34$, and $0.51 \mathrm{~kg} / \mathrm{d})$, showed no effect on milk fat content and production. In contrast to the present results, another study using grazing dairy cows supplemented with a mixture of fish and sunflower oils $(0.1 \mathrm{~kg}$ of fish oil $+0.3 \mathrm{~kg}$ of $\mathrm{SO} / \mathrm{d})$ reported no significant effect on milk production and composition (AbuGhazaleh and Holmes, 2007). Overall, the results of this study and the available literature on this topic suggest that supplementation with LO exerts no negative effects on milk fat content, when diets are mainly based on forage. The effect on milk fat 
Table 5. Least squares means for concentration of biohydrogenation intermediates $(\mathrm{mg} / 100 \mathrm{~g}$ of fatty acids) in milk fat from different dietary treatments ${ }^{1}$

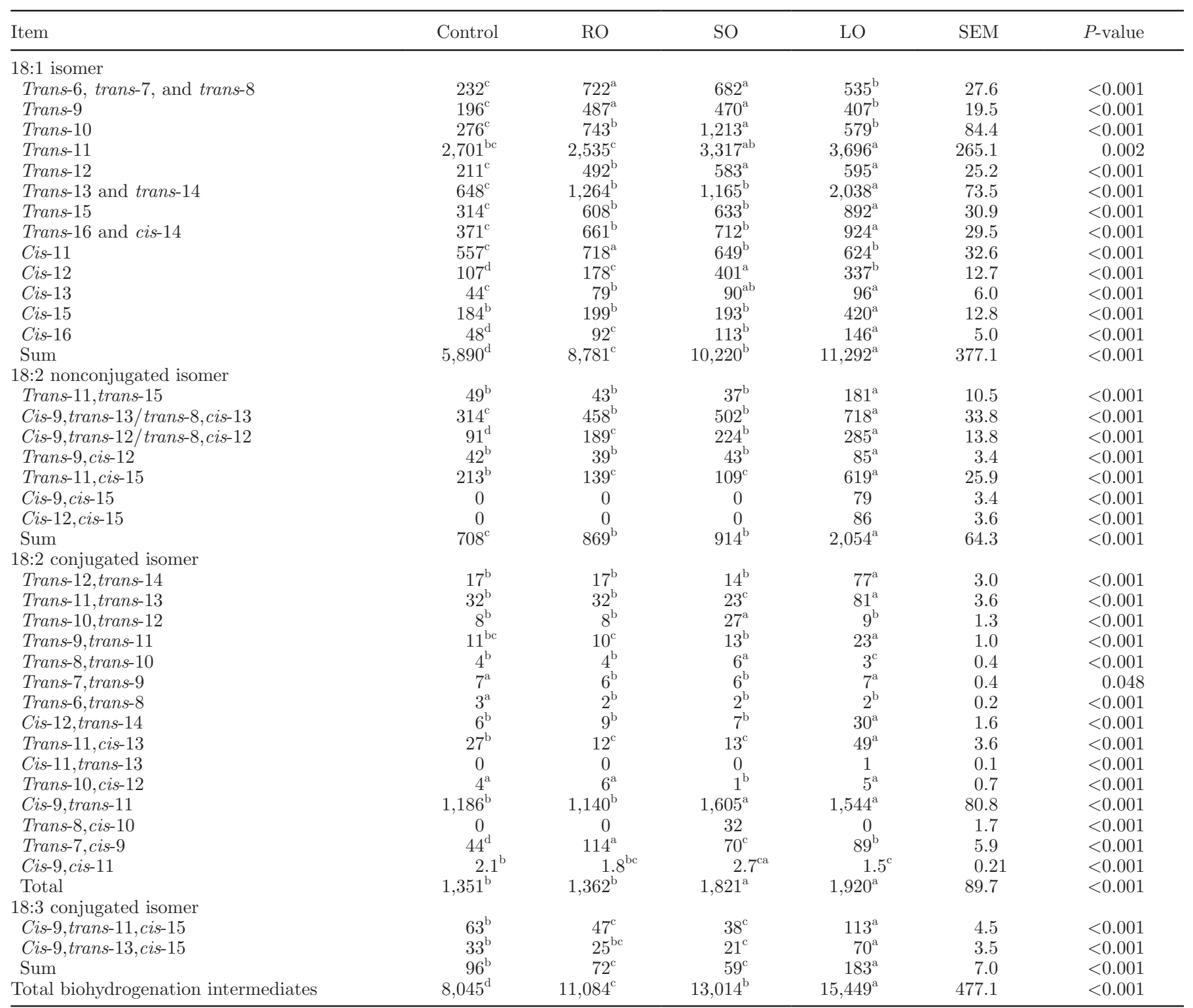

${ }^{\mathrm{a}-\mathrm{d}}$ Values in the same row that share a common superscript are not statistically different $(P>0.05)$.

${ }^{1}$ Treatments: control $=20$-h access to grazing pasture supplemented with $5 \mathrm{~kg} / \mathrm{d}$ of corn-based concentrate mixture $(96 \%$ corn, $\mathrm{CC}) ; \mathrm{RO}=20-\mathrm{h}$ access to grazing pasture supplemented with $4.5 \mathrm{~kg} / \mathrm{d}$ of $\mathrm{CC}$ and $0.5 \mathrm{~kg}$ of rapeseed oil; $\mathrm{SO}=20$-h access to grazing pasture supplemented with $4.5 \mathrm{~kg} / \mathrm{d}$ of $\mathrm{CC}$ and $0.5 \mathrm{~kg}$ of sunflower oil; $\mathrm{LO}=20$-h access to grazing pasture supplemented with $4.5 \mathrm{~kg} / \mathrm{d}$ of CC and $0.5 \mathrm{~kg}$ of linseed oil.

content of supplementation with oleic and linoleic acid sources seems to be less consistent in the literature.

\section{Milk FA Composition}

It has been well established that the inclusion of unsaturated fat in dairy cow diets inhibits the de novo synthesis of short- and medium-chain FA and increases the concentration of $\mathrm{C}_{18} \mathrm{FA}$, resulting in a more unsaturated milk fat (Chilliard et al., 2007). Odd- and branched-chain FA mainly originate from microbial matter in the rumen, and feeding unprotected lipid supplements to ruminants induces changes in the rumen microbial population that can result in a lower outflow of these FA. However, recently it was demonstrated that milk odd- and branched-chain FA are highly correlated with milk short- and medium-chain FA, and not with their duodenal concentration (Glasser et al., 2007b), suggesting that its concentration in milk would be mainly regulated at the mammary level (Glasser et 
Table 6. Negative linear relationships between milk fat content (\%) and milk biohydrogenation intermediates (g/100 g of fatty acids)

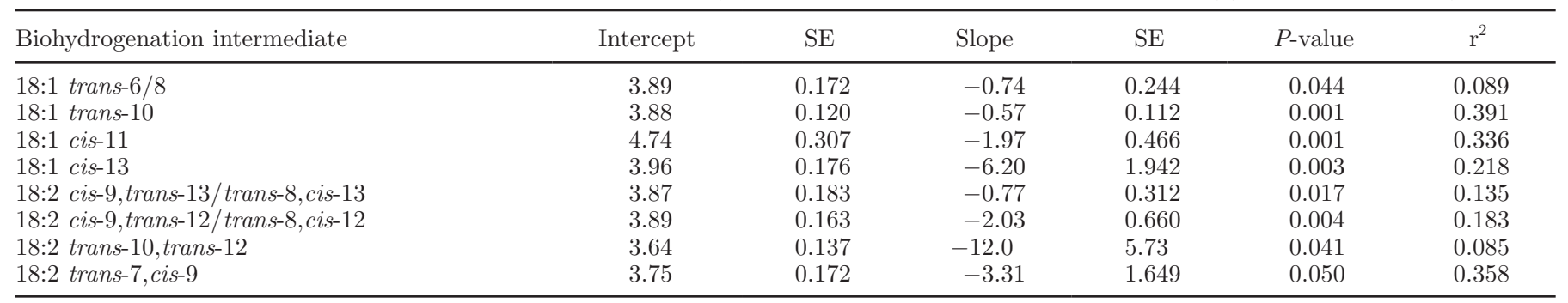

al., 2008b). The results of the present experiment are consistent with this pattern.

The proportion of 18:0 was higher when feeding vegetable oils, which it is in line with previous results (Rego et al., 2005). Increases in oleic acid can be attributed to differences in 18:1 intake (and duodenal flow of 18:1 cis-9) and to availability of 18:0 for $\Delta^{9}$-desaturation in the mammary gland, which is linked to a less complete biohydrogenation of 18:3n-3 than of 18:2n-6 (Glasser et al., 2008a). Linoleic acid was the highest, with SO reflecting the higher intake of 18:2n-6.

One objective of this study was to detect any positive additive or synergistic effect between pasture and LO because both are good sources of 18:3n-3. Surprisingly, LO lowered this FA in milk fat, yet this strategy failed to promote milk fat enrichment in n-3 FA. Conversely, Flowers et al. (2008), who supplemented grazing dairy cows with increasing levels of linseed oil $(0.17,0.34$, and $0.51 \mathrm{~kg} / \mathrm{d}$ ), observed an increase in 18:3n-3. A possible explanation for the reduction in 18:3n-3 in the milk fat of cows fed fat-supplemented diets might be a reduction of pasture intake. A reduction of pasture DMI (-3.9 $\mathrm{kg}$ of DM) after lipid supplementation (0.5 and $1.0 \mathrm{~kg}$ of partially hydrogenated oil) has been reported by Schroeder et al. (2002).

Fatty acid yields reflect the total fat yield and milk FA pattern. In contrast to supplementation with RO and SO, LO supplementation did not depress total milk fat yield, and this was reflected in yields of individual FA (not shown) and partial sums of FA.

\section{BI}

Although detailed BI profiles of milk from dairy cows fed mixed diets and conserved forages have been reported (as reviewed by Shingfield et al., 2008), milk BI profiles from grazing dairy cows have not. To our knowledge, this is the first detailed BI pattern, including the CLA isomeric profile by silver-ion HPLC, in the milk fat of grazing cows supplemented with vegetable oils. The general pattern of the BI profile reflects the pathways of ruminal metabolization of $18: 1$ cis-9, 18:2n6 , and 18:3n-3 and has similarities with those found in milk fat from nongrazing dairy cows, as reviewed by Chilliard et al. (2007) and Shingfield et al. (2008).

The magnitude and pattern of BI differed with the different vegetable oils supplemented. Rapeseed oil increased almost all 18:1 isomers, but not 18:1 trans-11, which might be explained mainly by the extensive isomerization of $18: 1$ cis-9, which is consistent with the results obtained in vitro with marked 18:1 cis-9 (Mosley et al., 2002). Our results support data indicating that 18:1 trans-11 is not the main product of rumen microbial isomerization of $18: 1 \mathrm{cis}-9$.

The increase in 18:2 trans- 7 , cis- 9 as well as in the unresolved peaks of 18:2 cis-9,trans-13/18:2 trans-8, cis-13 and 18:2 cis-9,trans-12/18:2 trans-8,cis-12 observed with $\mathrm{RO}$ was probably due to increased availability of the trans-7, trans-12, and trans-13 18:1 isomers that were submitted to $\Delta^{9}$-desaturation in mammary gland, producing, respectively, the trans- 7 , cis- 9 , cis-9,trans- 12 , and cis-9,trans-13 18:2 isomers. The $\Delta^{9}$-desaturation of these trans 18:1 isomers has been proposed previously (Corl et al., 2002; Loor et al., 2005). Overall, dietary oleic acid, as opposed to dietary linoleic and linolenic acids, consistently increased 18:1 trans-6, trans-7, and trans-8 and the trans-7,cis-9 CLA isomer in milk fat (Secchiari et al., 2003; Collomb et al., 2004a). According to Secchiari et al. (2003), trans-7, cis-9 is the second most representative CLA isomer in milk fat, in this study attaining $8.4 \%$ of the total CLA isomers for RO and attaining $3 \%$ for the control, SO, and LO treatments.

Consistent with the lack of response in 18:1 trans-11 to the RO diet, the proportion of 18:2 cis-9,trans-11 in milk fat also failed to increase. Conversely, either in grazing dairy cows (Lawless et al., 1998) or in grass silage-fed cows (Ryhãnen et al., 2005), supplementation with full-fat rapeseed meal $(1.65 \mathrm{~kg} / \mathrm{d}$; approximately $0.65 \mathrm{~kg}$ of oil) or rapeseed oil $(0.5 \mathrm{~kg} / \mathrm{d})$ increased 18:1 trans-11 and 18:2 cis-9,trans-11 in milk fat. Several studies (Kelly et al., 1998; Collomb et al., 2004b) have shown that the dietary sources of $18: 2 \mathrm{n}-6$, and to a lesser extent the 18:3n-3 sources, are more efficient in increasing those components in milk fat than are the 18:1 cis-9 sources. However, the inclusion of unsatu- 
rated fat (as vegetable oils or oilseeds) in dairy cow diets, mainly in grazing conditions, does not guarantee an enhancement of 18:1 trans-11 and 18:2 cis-9,trans-11 concentrations in milk fat (Kay et al., 2004).

The increase in 18:1 trans-11 and 18:2 cis-9,trans-11 in milk fat from grazing cows as a response to dietary PUFA-rich oils, as reported here for $\mathrm{SO}$ and LO, is in agreement with previous reports (Schroeder et al., 2004; Rego et al., 2005; AbuGhazaleh and Holmes, 2007; Flowers et al., 2008). Effects of sunflower oil supplementation on the pattern of BI agree with previous results from nongrazing dairy cows supplemented with either sunflower or linseed oil (Chilliard et al., 2007; Shingfield et al., 2008).

The increase in the trans nonconjugated 18:2 isomers found with LO was probably derived either directly from rumen biohydrogenation of 18:3n-3 (trans-11,cis-15, trans-9,cis-12, trans-11,trans-15, trans-8,cis-12, and trans-8,cis-13 18:2 isomers) or both directly and indirectly (i.e., cis-9,trans-12 and cis-9,trans-13 18:2 isomers) via $\Delta^{9}$-desaturation of the respective trans monoenes. However, at least 18:2 cis-9,trans-13 might also have a direct origin by the reduction of $18: 3$ cis9,trans-13, cis-15 (Destaillats et al., 2005). We confirmed that the conjugated 18:3 cis-9,trans-11, cis-15 and cis9, trans-13, cis-15 isomers occurred in cow's milk and that they were increased with LO (Figure 1). In milk from LO-fed cows, we also detected small concentrations of 18:2 cis-9, cis-15, as reported previously by Loor et al. (2005), and small concentrations of 18:2 cis-12,cis-15 (Figure 1). Alves and Bessa (2007) reported the occurrence of 18:2 cis-12, cis-15 (18:2n-3) in the muscles of lambs fed linseed oil and elucidated its structure, and Bessa et al. (2007) proposed it as a new BI of 18:3n-3. We could not detect this isomer either in control milk samples or, previously, in lambs fed dehydrated alfalfa (Bessa et al., 2007), which suggests that free linseed oil in the diet might be needed for the production of $18: 2$ cis-12, cis-15.

\section{Relationship Between BI and Milk Fat Content}

It has been hypothesized that some BI are the causative agents in milk fat depression (Harvatine et al., 2009). Although RO and SO depressed milk fat percentage, the degree of depression $(-12 \%)$ was far from those reported for extreme milk fat depression (approximately $-50 \%$ ). Moreover, concentrations of both 18:1 trans-10 and 18:2 trans-10,cis-12 were low, indicating that no expressive trans-10 shift had occurred in the rumen biohydrogenation pathways. The LO induced the highest amount and diversity of BI without decreasing milk fat concentration, as RO and SO had. This suggests that the BI associated with 18:3n-3 intake may not be the major contributors to the inhibition of mammary milk fat synthesis. The regression between BI and milk fat revealed some linear negative relationships $(P$ $\leq$ 0.05; Table 6 ). The 18:1 trans-10 and 18:2 trans10 ,cis-12 have been consistently reported as negatively correlated with milk fat (Kadegowda et al., 2008). In our data, 18:1 trans-10 presented the highest $\mathrm{R}^{2}$, although 18:2 trans-10,cis-12 was not related to milk fat. A direct effect on milk fat depression was demonstrated only for 18:2 trans-10,cis-12, whereas for 18:1 trans-10, demonstration of this effect was lacking (Lock et al., 2007), although it cannot be excluded. As pointed out by Kadegowda et al. (2008), the 18:1 trans-10 concentration in milk fat achieved by Lock et al. (2007) was well below the expected threshold concentration to allow detection of its effects on milk fat depression.

Our data revealed an inverse relationship between milk fat and several 18:1 (trans-6/9, cis-11, and cis13) and 18:2 (cis-9,trans-13/trans-8, cis-13, and cis9,trans-12/trans-8,cis-12) isomers, some unresolved, that to our knowledge have not been tested for a direct effect on milk fat depression (Harvatine et al., 2009). The eventual role of these isomers on milk fat depression cannot be ruled out at present.

\section{CONCLUSIONS}

This study showed that supplementing grazing dairy cows with vegetable oils of different FA compositions induced major changes in milk FA without any effect on milk responses, except for a decrease in milk fat content and production. Supplementation with vegetable oils reduced milk fat concentration of saturated FA and increased cis-MUFA, which can be considered an improvement in its nutritive value. Linseed oil supplementation failed to increase the 18:3n-3 content of milk fat. Supplementation with sunflower and linseed oils increased both rumenic (18:2 cis-9,trans-11) and vaccenic acids (18:1 trans-11), but also increased a diversity of other rumen biohydrogenation-derived trans FA. Linseed oil supplementation resulted in the highest concentration and diversity of BI.

\section{REFERENCES}

AbuGhazaleh, A. A., and L. D. Holmes. 2007. Diet supplementation with fish oil and sunflower oil to increase conjugated linoleic acid levels in milk fat of partially grazing dairy cows. J. Dairy Sci. 90:2897-2904

Agilent Technologies. 2001. Agilent Chemstation for LC 3D SystemsUnderstanding Your Spectra Module User's Guide. Agilent Technologies Inc., Palo Alto, CA.

Alves, S. P., and R. J. B. Bessa. 2007. Identification of cis-12,cis-15 octadecadienoic acid and other minor polyenoic fatty acids in ruminant fat. Eur. J. Lipid Sci. Technol. 109:879-883.

AOAC. 1990. Official Methods of Analysis. 15th ed. Vol. 1. Assoc. Off. Anal. Chem., Arlington, VA. 
Bessa, R. J. B., S. P. Alves, E. Jerónimo, C. M. Alfaia, J. A. M. Prates, and J. Santos-Silva. 2007. Effect of lipid supplements on ruminal biohydrogenation intermediates and muscle fatty acids in lambs. Eur. J. Lipid Sci. Technol. 109:868-878.

Chilliard, Y., F. Glasser A. Ferlay, L. Bernard, J. Rouel, and M. Doreau. 2007. Diet, rumen biohydrogenation and nutritional quality of cow and goat milk fat. Eur. J. Lipid Sci. Technol. 109:828-855.

Collomb, M., R. Sieber, and U. Butikofer. 2004a. CLA isomers in milk fat from cows fed diets with high levels of unsaturated fatty acids. Lipids 39:355-364.

Collomb, M., H. Sollberger, U. Butikofer, R. Sieber, W. Stoll, and W. Schaeren. 2004b. Impact of a basal diet of hay and fodder beet supplemented with rapeseed, linseed and sunflower seed on the fatty acid composition of milk fat. Int. Dairy J. 14:549-559.

Corl, B. A., L. H. Baumgard, J. M. Griinari, P. Delmonte, K. M. Morehouse, M. P. Yurawecz, and D. E. Bauman. 2002. Trans-7, cis-9 CLA is synthesized endogenously by $\Delta^{9}$-desaturase in dairy cows. Lipids 37:681-688.

Cruz-Hernandez, C., Z. Deng, J. Zhou, A. R. Hill, M. P. Yurawecz, P. Delmonte, M. M. Mossoba, M. E. R. Dugan, and K. J. G. Kramer. 2004. Methods for analysis of conjugated linoleic acid and trans-18:1 isomers in dairy fats by using a combination of gas chromatography, silver-ion thin-layer chromatography/gas chromatography, and silver-ion liquid chromatography. J. AOAC Int. 87:545-562.

Delmonte, P., J. A. G. Roach, M. M. Mossoba, K. M. Morehouse, L. Lehmann, and M. P. Yurawecz. 2003. Synthesis and isolation of trans-7,cis-9 octadecadienoic acid and other CLA isomers by base conjugation of partially hydrogenated $\gamma$-linolenic acid. Lipids 38:579-583.

Destaillats, F., J. P. Trottier, J. M. G. Galvez, and P. Angers. 2005. Analysis of $\alpha$-linolenic acid biohydrogenation intermediates in milk fat with emphasis on conjugated linoleic acids. J. Dairy Sci. 88:3231-3239.

European Economic Community. 1986. Council Directive 86/609/EEC: On the approximation of laws, regulations, and administrative provisions of the Member States regarding the protection of animals used for experimental and other scientific purposes. Off. J. L 358:1-28.

Flowers, G., S. A. Ibrahim, and A. A. AbuGhazaleh. 2008. Milk fatty acid composition of grazing dairy cows when supplemented with linseed oil. J. Dairy Sci. 91:722-730.

Glasser, F., M. Doreau, A. Ferlay, and Y. Chilliard. 2007a. Technical note: Estimation of milk fatty acid yield from milk fat data. J. Dairy Sci. 90:2302-2304.

Glasser, F., M. Doreau, A. Ferlay, J. Loor, and Y. Chilliard. 2007b. Milk fatty acids: Mammary synthesis could limit transfer from duodenum in cows. Eur. Lipid Sci. Technol. 109:817-827.

Glasser, F., A. Ferlay, and Y. Chilliard. 2008b. Oilseed lipid supplements and fatty acid composition of cow milk: A meta-analysis. J. Dairy Sci. 91:4687-4703.

Glasser, F., A. Ferlay, M. Doreau, P. Schmidely, D. Sauvant, and Y. Chilliard. 2008a. Long-chain fatty acid metabolism in dairy cow: A meta-analysis of milk fatty acid yield in relation to duodenal flows and de novo synthesis. J. Dairy Sci. 91:2771-2785.

Harvatine, K. J., Y. R. Boisclair, and D. L. Bauman. 2009. Recent advances in regulation of milk fat. Animal $3: 40-54$

Kadegowda, A. K. G., L. S. Piperova, and R. A. Erdman. 2008. Principal component and multivariate analysis of milk long-chain fatty acid composition during diet-induced fat depression. J. Dairy Sci. 91:749-759.

Kay, J. K., T. R. Mackle, M. J. Auldist, N. A. Thomson, and D. E. Bauman. 2004. Endogenous synthesis of cis-9, trans-11 conjugated linoleic acid in dairy cows fed fresh pasture. J. Dairy Sci. 87:369378.

Kelly, M. L., J. R. Berry, D. A. Dwyer, J. M. Griinari, P. Y. Chouinard, M. E. Van Amburgh, and D. E. Bauman. 1998. Dietary fatty acid sources affect conjugated linoleic acid concentrations in milk fat from lactating dairy cows. J. Nutr. 128:881-885.
Lawless, F., J. J. Murphy, D. Harrington, R. Devery, and C. Stanton. 1998. Elevation of conjugated cis-9, trans-11-octadecadienoic acid in bovine milk because dietary supplementation. J. Dairy Sci. 81:3259-3267.

Lock, A. L., C. Tyburczy, D. A. Dwyer, K. J. Harvatine, F. Destaillats, Z. Mouloungui, I. Candy, and D. E. Bauman. 2007. Trans-10 octadecenoic acid does not reduce milk fat synthesis in dairy cows. J. Nutr. 137:71-76.

Loor, J. J., A. Ferlay, A. Ollier, K. Ueda, M. Doreau, and Y. Chilliard 2005. Relationship among trans and conjugated fatty acids and bovine milk fat yield due to dietary concentrate and linseed oil. J. Dairy Sci. 88:726-740.

Luthria, D. L., and H. Sprecher. 1993. 2-Alkenyl-4,4-dimethyloxazolines as derivatives for the structural elucidation of isomeric unsaturated fatty acids. Lipids 28:561-564.

Molkentin, J., and D. Precht. 2000. Validation of gas-chromatographic method for the determination of milk fat contents in mixed fats by butyric acid analysis. Eur. J. Lipid Sci. Technol. 102:194-210.

Mosley, E. E., G. L. Powell, M. B. Riley, and T. C. Jenkins. 2002. Microbial biohydrogenation of oleic acid to trans isomers in vitro. J. Lipid Res. 43:290-296.

Rego, O. A., H. J. D. Rosa, P. V. Portugal, T. Franco, C. M. Vouzela, A. E. S. Borba, and R. J. B. Bessa. 2005. The effects of supplementation with sunflower and soybean oils on the fatty acid profile of milk fat from grazing dairy cows. Anim. Res. 54:1724 .

Rego, O. A., H. J. D. Rosa, S. M. Regalo, S. P. Alves, C. M. M Alfaia, J. A. M. Prates, C. M. Vouzela, and R. J. B. Bessa. 2008. Seasonal changes of CLA isomers and other fatty acids of milk fat from grazing dairy herds in the Azores. J. Sci. Food Agric. $88: 1855-1859$.

Robertson, J. B., and P. J. Van Soest. 1981. The detergent system of analysis and its application in human diets. Pages 123-158 in The Analysis of Dietary Fiber in Food. W. P. T. James and O. Theander, ed. Marcel Dekker Inc., New York, NY.

Ryhãnen, E. L., K. Tallawaara, J. M. Griinari, S. Jaakkola, S. MantereAlhonen, and K. J. Shingfield. 2005. Production of conjugated linoleic acid enriched milk and dairy products from cows receiving grass silage supplemented with a cereal-based concentrate containing rapeseed oil. Int. Dairy J. 15:207-217.

Salomonsson, A., A. Theander, and E. Westerlund. 1984. Chemical characterization of some Swedish cereal whole meal and bran fractions. Swed. J. Agric. Res. 14:111-117.

Schroeder, G. F., G. A. Gagliostro, F. Bargo, J. E. Delahoy, and L. D. Muller. 2004. Effect of fat supplementation on milk production and composition by dairy cows on pasture: A review. Livest. Prod. Sci. 86:1-18.

Schroeder, G. F., G. A. Gagliostro, D. Becu-Villalobos, and I. LacauMengido. 2002. Supplementation with partially hydrogenated oil in grazing dairy cows in early lactation. J. Dairy Sci. 85:580-594.

Secchiari, P., M. Antongiovanni, M. Mele, A. Serra, A. Buccioni, G. Ferruzi, F. Paoletti, and F. Petacchi. 2003. Effect of kind of dietary fat on the quality of milk fat from Italian Frisian cows. Livest. Prod. Sci. 83:43-52.

Shingfield, K. J., Y. Chilliard, V. Toivonen, P. Kairenius, and D. I. Givens. 2008. Trans fatty acids and bioactive lipids in ruminant milk. Adv. Exp. Med. Biol. 606:3-65.

St-Pierre, N. R. 2001. Invited review: Integrating quantitative findings from multiple studies using mixed model methodology. J. Dairy Sci. 84:741-755.

Sukhija, P. S., and D. L. Palmquist. 1988. Rapid method for determination of total fatty-acid content and composition of feedstuffs and feces. J. Agric. Food Chem. 36:1202-1206.

Van Soest, P. J., J. B. Robertson, and B. A. Lewis. 1991. Symposium: carbohydrate methodology, metabolism, and nutritional implications in dairy cattle. Methods for dietary fiber, neutral detergent fiber, and nonstarch polysaccharides in relation to animal nutrition. J. Dairy Sci. 74:3583-3597. 